\title{
INCREASED SPONTANEOUS ACTIVITY AND FOOD INTAKE PRODUCED IN RATS BY REMOVAL OF THE FRONTAL POLES OF THE BRAIN
}

\author{
BY \\ C. P. RICHTER and C. D. HAWKES \\ From the Psychobiological Laboratory, Henry Phipps Psychiatric Clinic, \\ The Johns Hopkins Hospital
}

(Received 1ST MARCH, 1939)

Previous experiments upon monkeys investigated from a quantitative standpoint the disputed problem of the rôle played by the frontal lobes in the regulation and control of spontaneous activity (Richter and Hines, 1938). Both the cortex and the underlying striatum were found to participate. The failure of unilateral lesions to increase activity significantly unless the lesion included at least the tip of the striatum demonstrated that the striatum plays an important part in this phenomenon. The production of increased activity by bilateral lesions limited to the cortex, entirely sparing the striatum, demonstrated that the cortex (particularly area 9) also plays an important part.

Much of the early work in this field was based on incidental and casual observations of animals and patients with frontal lobe disturbances. In the experiments on monkeys the use of a special cage equipped with a recording device for the exact measurement of activity eliminated this objection. However, the small number of animals used and the lack of sufficient information concerning the normal activity level of monkeys left much to be desired. For example, we did not know whether the lesions simply made inactive animals more active or normally active animals abnormally active. Furthermore, we had no way of evaluating the changes in behaviour and metabolism which accompany the activity increase.

In order to overcome these difficulties rats were used as experimental subjects. Previous studies on their normal activity, behaviour, and metabolism provided baselines for the changes brought about by this type of experimentation. This report deals with the changes in activity levels resulting from only one type of lesion, the removal of the frontal poles, including the tip of the striatum. This lesion was chosen because experience has shown it to be the easiest to produce in a uniform manner, and because the experiments on monkeys indicated that it would result in a maximum increase in activity, even when only unilateral.

For these experiments we selected two groups of animals, one which was 231 
much less active than the normal average and another which was definitely much more active than the normal average. Since any increase in activity would be more easily detected in inactive animals, we started our experiments with this group. We wanted to know whether removal of a frontal pole could increase their activity at least to the normal average. Further, in order to determine whether the operation could actually make the rats hyperactive, that is, attain levels never reached by normal rats, we used animals which at the outset had attained maximum normal activity.

In addition to the study of quantitative changes in activity, the effects of the lesions on food and water intake, body weight, vaginal smears, general behaviour, and on the endocrine glands were observed. Such a complete study permits deductions to be made concerning the mechanism of production of the activity change.

\section{Methods}

The cages used for measuring activity contained a small living compartment with a food box (standard McCollum diet), an inverted graduated water bottle, and a revolving drum with a cyclometer. Previous papers contain a more detailed description of the cages and stands (Richter, 1927).

Records were made daily of activity, food, and water intake, and of the vaginal smears ; and weekly of body weight.

From previous experiments (Wang, 1923) it is known that rats placed in the cages at 40 to 45 days of age begin to run within a few days and usually attain their maximum level of activity within the next 15 days. When rats do not run at all within the first 15 to 20 days after being placed in the cages, they rarely start running later on. At the height of their running activity normal female rats average approximately 11,000 revolutions per day ; males approximately 10,000 revolutions. The range of variation, however, is quite wide. Thus, some otherwise normal animals for reasons of heredity or for some as yet unexplained reason never attain an average of 2,000 revolutions per day. Such animals are rare in our colony. A small number of normals have attained an average of 14,000 to 20,000 revolutions per day.

For the purposes of the present experiment we selected one group of 12 rats which were extremely inactive (with averages of 2,000 revolutions or less) and gave all indications of remaining so indefinitely, and another group of six rats which were extremely active, showing averages of 14,000 revolutions per day or better, which is maximal for animals of their age. As controls for this active group we selected ten rats all of which had activity averages equally or surpassing the normal level.

Seven animals of the inactive group had only one frontal lobe removed ; five had both lobes removed in two stages separated by 24 days. The six rats of the active group had both frontal poles removed, also in two stages.

The operative technique was essentially the same as that used on monkeys. Using binocular operating glasses, we made a midline scalp incision $1 \mathrm{~cm}$. long exposing the frontal and parietal sutures in the skull of the anæsthetized animals. After scraping the fascia from the bone, we made a circular hole $2 \mathrm{~mm}$. in diameter with a dental trephine just posterior to the frontal suture, taking care not to tear the meninges. Through a small hole made in the meninges with a needle we inserted a bevelled-edged glass canula and with negative pressure from a faucet pump sucked out the brain tissue. In order to avoid the bleeding which almost invariably results from tearing the meninges, we inserted the canula several millimeters into the brain tissue before applying the suction pressure. By gradual withdrawal of the canula we could remove the brain tissue directly under the meninges with minimal damage to the meninges themselves. Movement of the canula perpendicularly down to the base of the skull, 
to the sides, and anteriorly so far as possible, permitted the removal of a fairly constant amount of brain tissue in every animal.

The animals required considerable attention post-operatively, especially after the second operation. For a period of 2 to 10 days they had difficulty in reaching their food cups and water bottles and in eating the powdered McCollum food. For this reason we left milk-soaked bread in the cages at all times, until the animals again ate the McCollum diet in normal amounts.

All of the animals were autopsied. The endocrine glands were weighed and preserved for histological study. The brains were removed, photographed, and preserved in formalin. They were sectioned and stained with Spielmeyer's stain or hæmatoxylin and eosin.

\section{Results}

Effects Produced on Spontaneous Activity : A. Inactive animals.-Unilateral frontal lobe removal consistently made all of the inactive animals more active, and some of them as active or even more active than the normal controls. Fig. 1

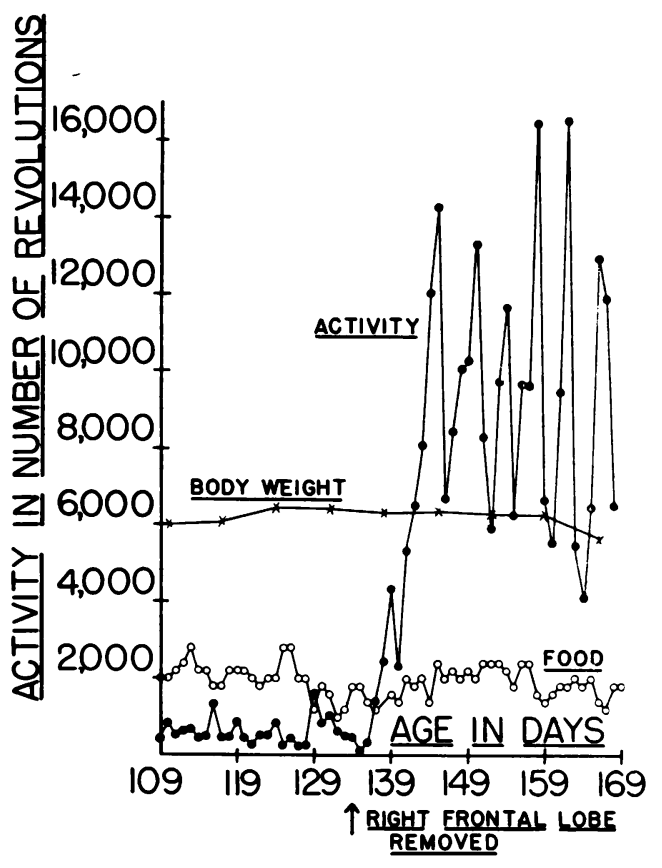

Fig. 1.-Chart showing the increase in spontaneous activity produced in an inactive animal by unilateral removal of the frontal pole.

gives the record of one animal in which the removal of one frontal pole increased the activity from a daily average of 460 revolutions to an average of 10,116 revolutions on the plateau 10 to 20 days afterwards. The animal became more active on the third day following the operation. Table 1 summarizes the results of the unilateral experiments. It gives the average daily activity for seven rats for the 10-day period immediately preceding the operation and for a 10-day period post-operatively when the activity had reached its highest plateau. The 
average daily activity increased from 778 to 9,726 revolutions. Some of the animals showed a much greater increase, as for instance, rat \#6, whose activity increased from 150 to 16,129 revolutions. Since these high levels were maintained until we killed the animals, usually at least $2-3$ months post-operatively, we have good reason to feel that the effects were permanent.

Table 1.-Unilateral Frontal Lobectomy (Inactive Animals)

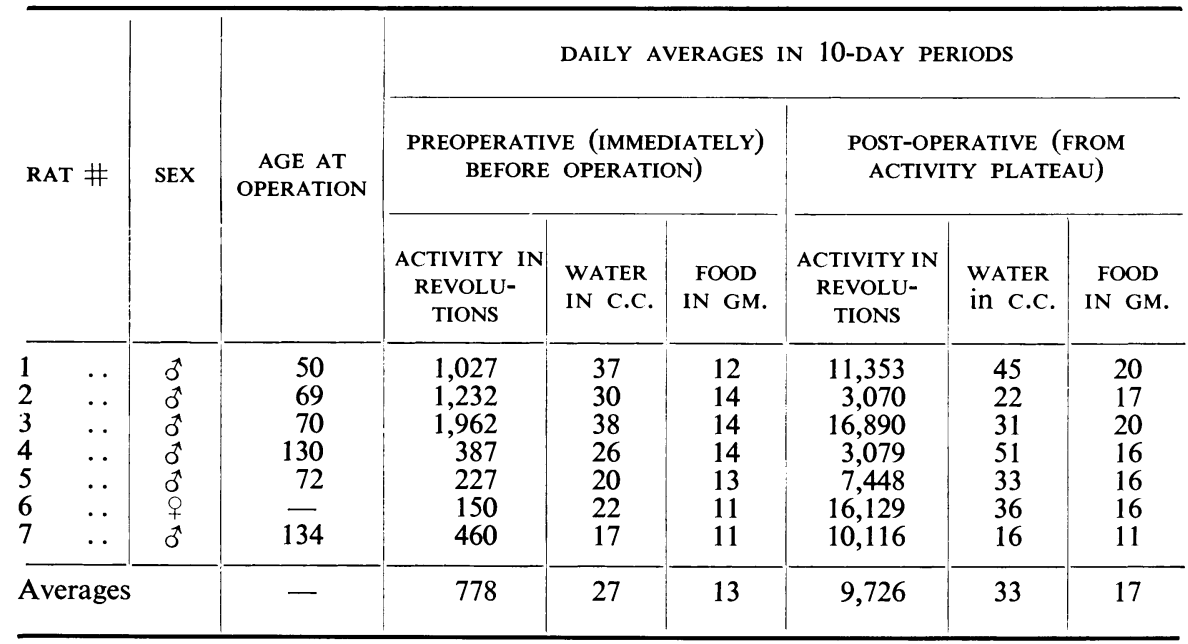

Table 2 gives the results of experiments in which both poles were removed. These five animals were extremely inactive, averaging only 150 revolutions per day preoperatively. Although the unilateral removal increased the activity

Table 2.-Bilateral Frontal Lobectomy (Inactive Animals)

\begin{tabular}{|c|c|c|c|c|c|c|c|c|c|c|c|}
\hline \multirow{3}{*}{ RAT \# } & \multirow{3}{*}{ SEX } & \multirow{3}{*}{$\begin{array}{l}\text { AGE AT } \\
\text { 1ST } \\
\text { OPERA- } \\
\text { TION }\end{array}$} & \multicolumn{9}{|c|}{ DAILY AVERAGES IN 10-DAY PERIODS } \\
\hline & & & \multicolumn{3}{|c|}{$\begin{array}{c}\text { PREOPERATIVE } \\
\text { (IMMEDIATELY } \\
\text { BEFORE OPERATION) }\end{array}$} & \multicolumn{3}{|c|}{$\begin{array}{c}\text { POST-OPERATIVE-1ST } \\
\text { (FROM ACTIVITY } \\
\text { PLATEAU) }\end{array}$} & \multicolumn{3}{|c|}{$\begin{array}{c}\text { POST-OPERATIVE-2ND } \\
\text { (FROM ACTIVITY } \\
\text { PLATEAU) }\end{array}$} \\
\hline & & & $\begin{array}{l}\text { ACTIVITY } \\
\text { IN } \\
\text { REVOLU- } \\
\text { TIONS }\end{array}$ & $\begin{array}{l}\text { WATER } \\
\text { IN } \\
\text { C.C. }\end{array}$ & $\begin{array}{l}\text { FOOD } \\
\text { IN } \\
\text { GM. }\end{array}$ & \begin{tabular}{|} 
ACTIVITY \\
IN \\
REVOLU- \\
TIONS
\end{tabular} & $\begin{array}{l}\text { WATER } \\
\text { IN } \\
\text { C.C. }\end{array}$ & $\begin{array}{l}\text { FOOD } \\
\text { IN } \\
\text { GM. }\end{array}$ & $\begin{array}{l}\text { ACTIVITY } \\
\text { IN } \\
\text { REVOLU- } \\
\text { TIONS }\end{array}$ & \begin{tabular}{|} 
WATER \\
IN \\
C.C.
\end{tabular} & $\begin{array}{l}\text { FOOD } \\
\text { IN } \\
\text { GM. }\end{array}$ \\
\hline $\begin{array}{l}\cdots \\
\cdots \\
\cdots \\
\cdots\end{array}$ & $\begin{array}{l}0 \\
0 \\
0 \\
0 \\
0 \\
0 \\
0\end{array}$ & $\begin{array}{l}-18 \\
57 \\
58 \\
81\end{array}$ & $\begin{array}{r}46 \\
96 \\
405 \\
158 \\
47\end{array}$ & $\begin{array}{l}17 \\
20 \\
28 \\
23 \\
19\end{array}$ & $\begin{array}{l}10 \\
14 \\
14 \\
14 \\
12\end{array}$ & $\begin{array}{r}117 \\
2,280 \\
758 \\
180 \\
178\end{array}$ & $\begin{array}{l}25 \\
23 \\
25 \\
23 \\
19\end{array}$ & $\begin{array}{l}12 \\
14 \\
18 \\
18 \\
14\end{array}$ & $\begin{array}{r}446 \\
4,922 \\
7,173 \\
2,494 \\
6,951\end{array}$ & $\begin{array}{l}26 \\
24 \\
27 \\
25 \\
24\end{array}$ & $\begin{array}{r}9 \\
9 \\
14 \\
14 \\
14\end{array}$ \\
\hline Averages & . . & - & 150 & 21 & 13 & 703 & 23 & 15 & 4,397 & 25 & 12 \\
\hline
\end{tabular}


many times over the preoperative level, the animals still were fairly inactive, averaging only 703 revolutions per day. The removal of the other pole increased

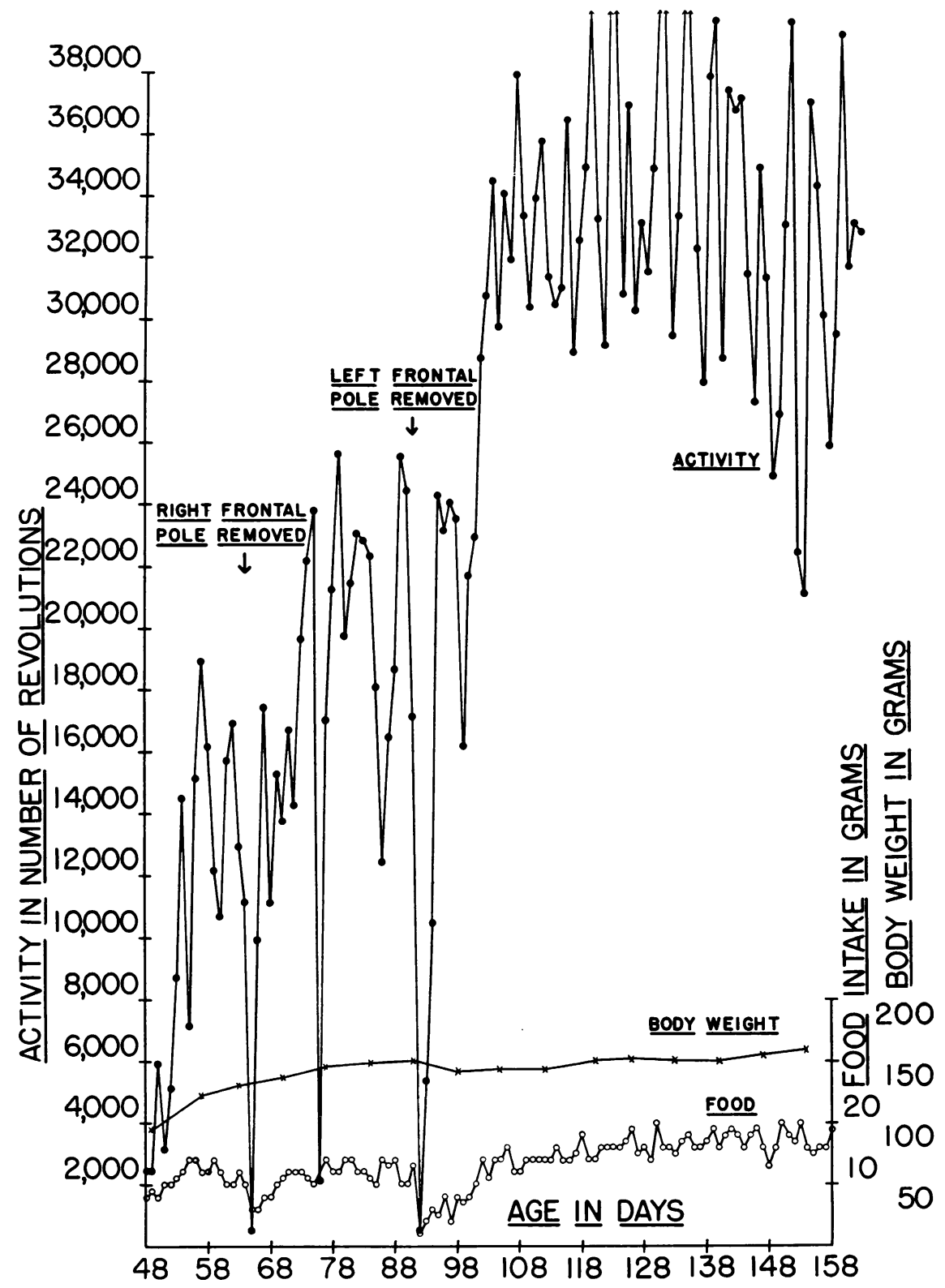

Fig. 2.-Chart showing the effect of bilateral frontal pole removal in an inactive animal on spontaneous activity, body weight, and food intake.

the activity to an average of 4,397 revolutions for the 10-day plateau period. However, the animals were still less active than normals.

The results of these experiments demonstrate that in rats, just as in monkeys, 
frontal pole lesions may greatly increase spontaneous activity. They do not show, however, that these lesions make animals hyperactive, that is, definitely more active than normals. It seemed possible that the failure of these operations to increase the activity to higher levels might have been due to some debility or defective urge of these animals, reflected in the low preoperative levels. For this reason similar experiments were made on a group of animals which preoperatively were very active and unquestionably normal and in good health.

B. Active animals.-Unilateral removal of the frontal pole made the active

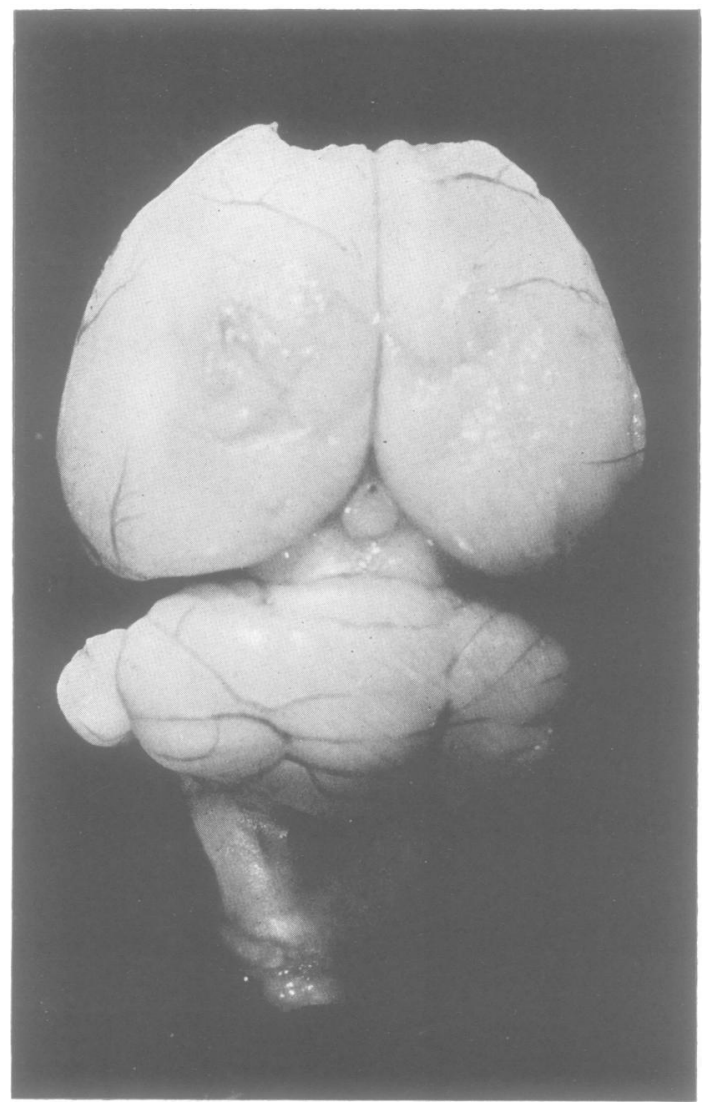

Fig. 3.-Photograph of the brain of Rat \#3 of Table 3 showing the lesions producing the effects illustrated in Fig. 2.

animals moderately more active. The removal of the other pole, however, in all instances increased activity well above the range attained by normals. Fig. 2 gives the record of one of these animals. Removal of the right pole increased the activity from 15,000 revolutions to 22,000 revolutions ; removal of the other pole increased the activity to 36,000 revolutions. The large fluctuations present preoperatively and even after the first operation disappeared almost entirely after the second operation. Fig. 3 shows the photograph of the dorsal 
surface of this animal's brain. Fig. 4 gives the record of another animal. This is presented because of the two $8-10$ day periods of relative inactivity which

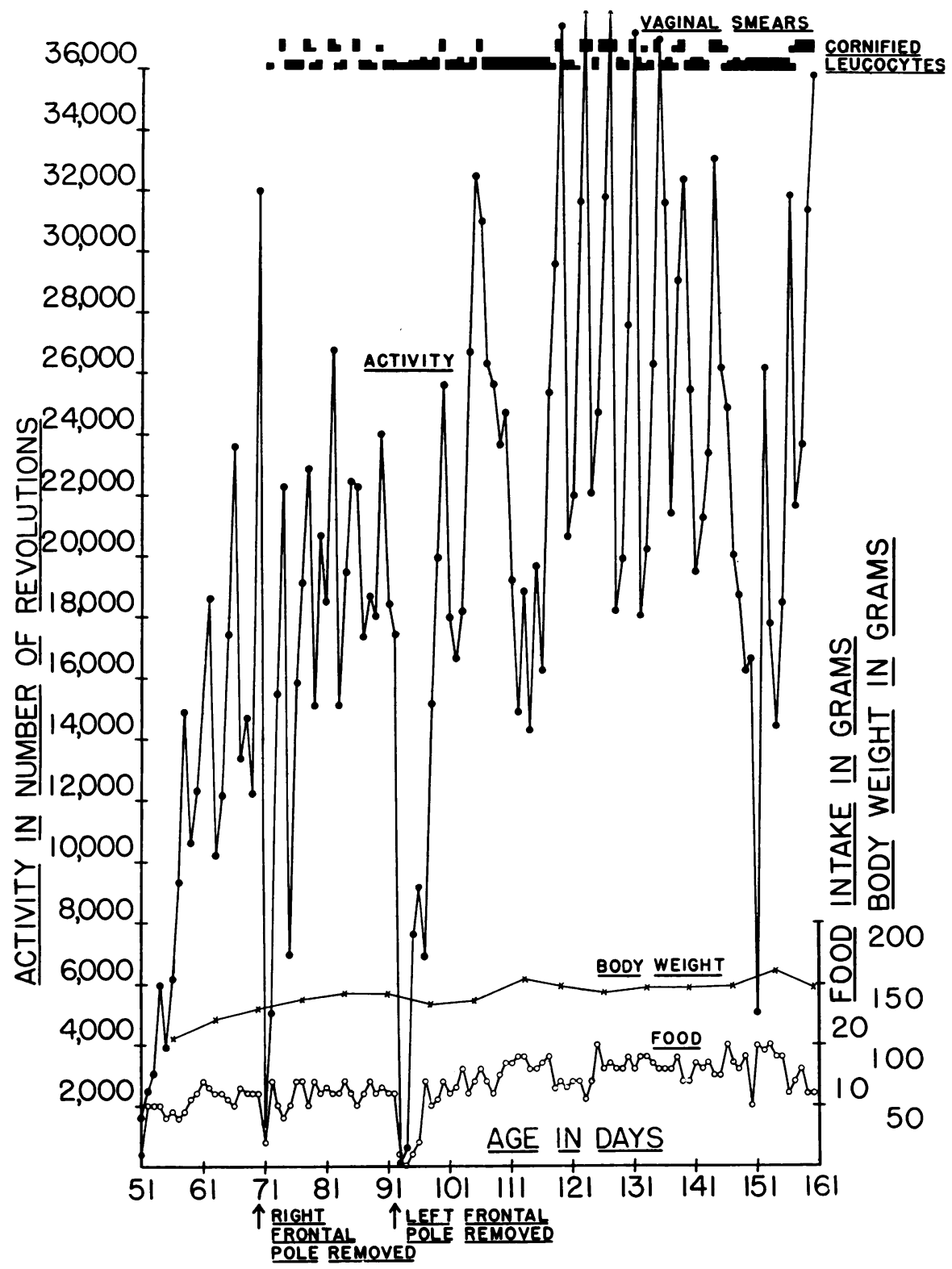

Fig. 4.-Chart showing period of exhaustion during the great increase in spontaneous activity following bilateral frontal pole removal.

occurred after the removal of the second pole. It appeared that before each of these periods the animal had run itself almost to the point of complete exhaustion and no longer was able to maintain the high level of activity. 
Table 3 summarizes the results of these experiments. The average daily activity increased from 17,828 revolutions per day to 21,662 after the first operation and to 31,040 after the second operation. One animal ran 44,000 revolutions on one day. This is equivalent to $28 \cdot 3$ miles.

\section{Table 3.-Bilateral Frontal Lobectomy \\ (Active Animals)}

\begin{tabular}{|c|c|c|c|c|c|c|c|c|c|c|c|}
\hline \multirow{3}{*}{ RAT \# } & \multirow{3}{*}{ SEX } & \multirow{3}{*}{$\begin{array}{l}\text { AGE AT } \\
\text { 1ST } \\
\text { OPERA- } \\
\text { TION }\end{array}$} & \multicolumn{9}{|c|}{ DAILY AVERAGES IN 10-DAY PERIODS } \\
\hline & & & \multicolumn{3}{|c|}{$\begin{array}{c}\text { PREOPERATIVE } \\
\text { (IMMEDIATELY } \\
\text { BEFORE OPERATION) }\end{array}$} & \multicolumn{3}{|c|}{$\begin{array}{l}\text { POST-OPERATIVE-1ST } \\
\text { (FROM ACTIVITY } \\
\text { PLATEAU) }\end{array}$} & \multicolumn{3}{|c|}{$\begin{array}{c}\text { POST-OPERATIVE-2ND } \\
\text { (FROM ACTIVITY } \\
\text { PLATEAU) }\end{array}$} \\
\hline & & & $\begin{array}{l}\text { ACTIVITY } \\
\text { IN } \\
\text { REVOLU- } \\
\text { TIONS }\end{array}$ & $\begin{array}{c}\text { WATER } \\
\text { IN } \\
\text { C.C. }\end{array}$ & $\begin{array}{c}\text { FOOD } \\
\text { IN } \\
\text { GM. }\end{array}$ & \begin{tabular}{|} 
ACTIVITY \\
IN \\
REVOLU- \\
TIONS
\end{tabular} & \begin{tabular}{|} 
WATER \\
IN \\
C.C.
\end{tabular} & $\begin{array}{c}\text { FOOD } \\
\text { IN } \\
\text { GM. }\end{array}$ & $\begin{array}{c}\text { ACTIVITY } \\
\text { IN } \\
\text { REVOLU- } \\
\text { TIONS }\end{array}$ & $\begin{array}{c}\text { WATER } \\
\text { IN } \\
\text { C.C. }\end{array}$ & $\begin{array}{l}\text { FOOD } \\
\text { IN } \\
\text { GM. }\end{array}$ \\
\hline $\begin{array}{l}1 \\
2 \\
3 \\
4 \\
5 \\
6\end{array}$ & $\begin{array}{l}\text { o } \\
o \\
+ \\
q \\
+ \\
+ \\
o \\
+ \\
+\end{array}$ & $\begin{array}{l}64 \\
64 \\
64 \\
64 \\
70 \\
69\end{array}$ & $\begin{array}{l}18,762 \\
14,964 \\
14,051 \\
26,940 \\
14,878 \\
17,374\end{array}$ & $\begin{array}{l}32 \\
21 \\
19 \\
20 \\
36 \\
28\end{array}$ & $\begin{array}{l}13 \\
12 \\
12 \\
13 \\
12 \\
11\end{array}$ & $\begin{array}{l}20,087 \\
22,629 \\
20,380 \\
25,825 \\
20,286 \\
20,767\end{array}$ & $\begin{array}{l}24 \\
22 \\
21 \\
23 \\
38 \\
30\end{array}$ & $\begin{array}{l}13 \\
13 \\
13 \\
13 \\
12 \\
13\end{array}$ & $\begin{array}{l}29,735 \\
33,025 \\
35,396 \\
28,448 \\
30,481 \\
29,153\end{array}$ & $\begin{array}{l}24 \\
24 \\
20 \\
20 \\
18 \\
27\end{array}$ & $\begin{array}{l}17 \\
16 \\
16 \\
16 \\
16 \\
15\end{array}$ \\
\hline Averages & . & 66 & 17,828 & 26 & 12 & 21,662 & 26 & 13 & 31,040 & 22 & 16 \\
\hline
\end{tabular}

Fig. 5 shows average activity curves for these six experimental animals and for the ten controls. The experimental animals were approximately twice as active as the normals. Since the activity of some of the experimental animals was still increasing at the time they were killed, it is possible that after several months they might have attained even higher levels.

Effects Produced on Food Intake : A. Inactive animals.-In this group the unilateral frontal pole operation produced a small but definite increase in food intake. Table 1 summarizes the results. The food intake increased from a daily average of $13 \mathrm{gm}$. for the 10-day period immediately preceding the operation to an average of $17 \mathrm{gm}$. post-operatively when the activity had reached a constant level. The food intake of the five animals with bilateral operations also increased after the first operation, but showed a decrease after the second. B. Active animals.-The food intake curves in Fig. 2 show the marked effect produced by bilateral removal of the frontal poles. Before the first operation the food intake averaged $12 \mathrm{gm}$. per day, and afterwards still averaged approximately the same. After the second operation, however, it increased to a level near $16 \mathrm{gm}$. Fig. 4 shows a similar effect. Table 3 summarizes the results for the six animals. The food intake increased from $12 \mathrm{gm}$. per day before operation to $13 \mathrm{gm}$. after the first operation and to $16 \mathrm{gm}$. after the second. That the food intake actually increased above the normal level is shown in Fig. 5, which gives the intake of these six experimental rats and of ten normal controls. After the first operation the average daily food intake of the hyper- 
active rats was slightly below the normal average, while after the second operation it was higher by about $3 \mathrm{gm}$.

Effect Produced on Water Intake.-A study of the graphs and of the tables shows that removal of the frontal poles did not increase water intake; if anything, it decreased the intake very slightly.

Effect on Vaginal Smears.-The vaginal smears were recorded only in the

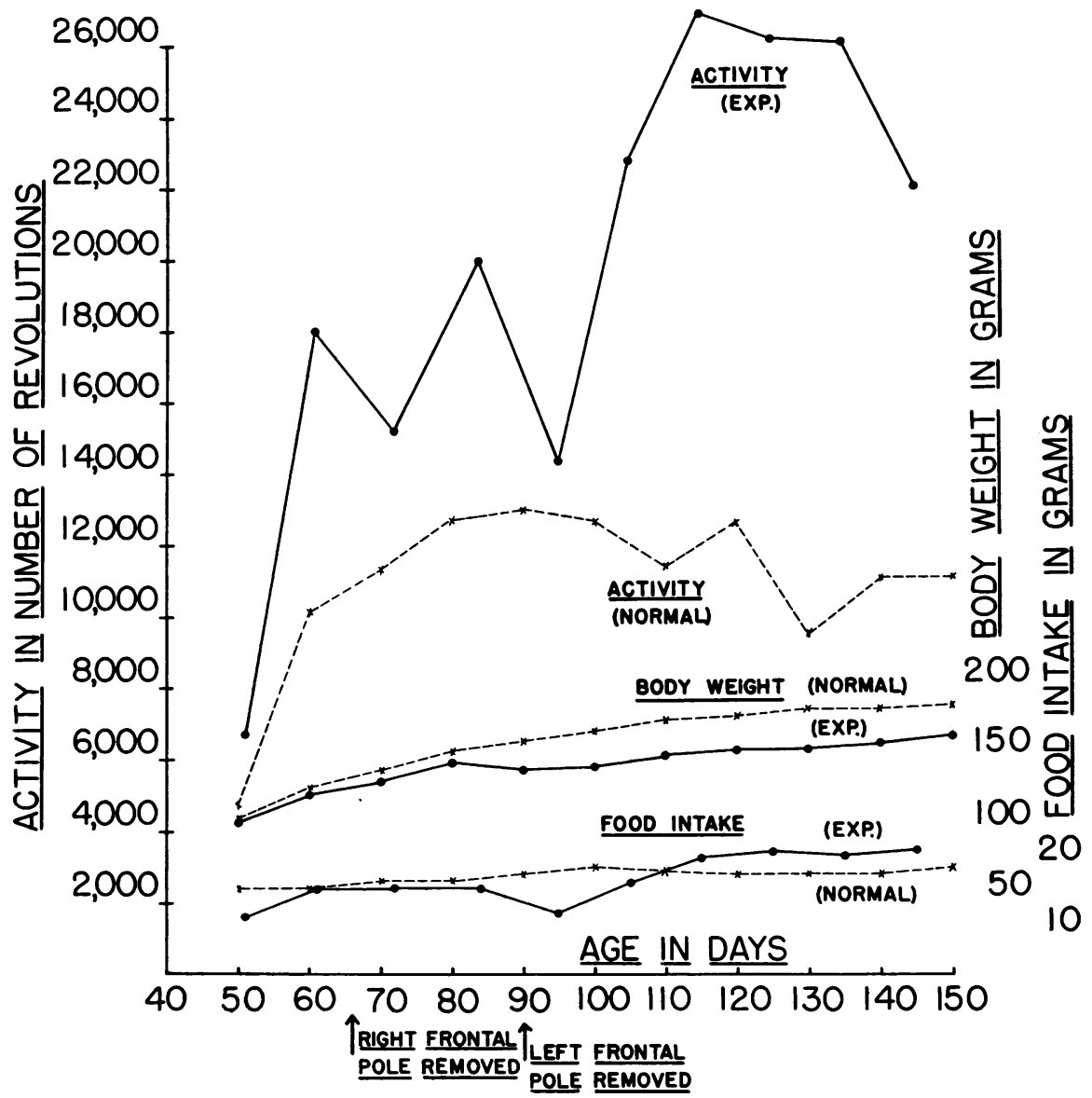

Fig. 5.-Chart comparing activity, body weight, and food intake in six frontal lobectomized female rats (unbroken line) with ten normal controls (dotted line).

six active animals. After the removal of one frontal pole all six of the animals showed the regular 4- to 5-day cycles, both in vaginal smears and activity, the days of cornification corresponding with the peaks of activity. After the removal of the other pole, two of the animals continued to show regular vaginal smear cycles ; four showed regular cycles except for the occasional periods of 8 to 15 days, when the cornified cells disappeared completely and a typical diœstrous smear was obtained. It is noteworthy that these diœstrous periods coincided with periods of relative inactivity. Fig. 4 gives a graphic representation of the vaginal smears of one of these animals. 
Effects Produced on the Endocrine Glands.-Since we know that the glands of internal secretion play a very important part in the control of spontaneous activity (Richter, 1927), they were examined to determine whether the operations affected them in any way which might account for the increased activity.

\section{Table 4.-Weights of Endocrine Glands of Active Animals with Bilateral Frontal Lobectomy}

(In milligrams)

\begin{tabular}{|c|c|c|c|c|c|c|c|c|c|c|c|}
\hline & \multirow{2}{*}{ RAT \# } & \multirow{2}{*}{$\begin{array}{c}\text { BODY } \\
\text { WT. } \\
\text { (GM.) }\end{array}$} & \multicolumn{2}{|c|}{ ADRENALS } & \multirow{2}{*}{ PANCREAS } & \multirow{2}{*}{ THYMUS } & \multirow{2}{*}{ THYROID } & \multirow{2}{*}{$\begin{array}{l}\text { PITUI- } \\
\text { TARY }\end{array}$} & \multicolumn{2}{|c|}{ OVARIES } & \multirow{2}{*}{ UTERUS } \\
\hline & & & L. & R. & & & & & L. & R. & \\
\hline $\begin{array}{l}1 \\
2 \\
3 \\
4 \\
5 \\
6\end{array}$ & $\begin{array}{ll}\ldots & \ldots \\
\ldots & \ldots \\
\ldots & \ldots \\
\cdots & \ldots \\
\ldots & \ldots \\
\ldots & \ldots\end{array}$ & $\begin{array}{l}185 \\
158 \\
159 \\
190 \\
148 \\
158\end{array}$ & $\begin{array}{l}38 \\
21 \\
21 \\
24 \\
29 \\
21\end{array}$ & $\begin{array}{l}34 \\
17 \\
19 \\
19 \\
27 \\
22\end{array}$ & $\begin{array}{l}721 \\
748 \\
639 \\
747 \\
770 \\
811\end{array}$ & $\begin{array}{r}147 \\
72 \\
83 \\
74 \\
95 \\
109\end{array}$ & $\begin{array}{l}17 \\
16 \\
13 \\
16 \\
16 \\
13\end{array}$ & $\begin{array}{r}10 \\
8 \\
10 \\
9 \\
9 \\
9\end{array}$ & $\begin{array}{l}45 \\
41 \\
41 \\
20 \\
38 \\
36\end{array}$ & $\begin{array}{l}40 \\
41 \\
35 \\
30 \\
40 \\
42\end{array}$ & $\begin{array}{l}535 \\
542 \\
720 \\
437 \\
428 \\
326\end{array}$ \\
\hline \multicolumn{2}{|c|}{$\begin{array}{c}\text { Averages } \\
\text { mgm. }\end{array}$} & 166 & \multicolumn{2}{|c|}{$\underbrace{0+1}_{49}$} & 739 & 97 & 15 & 9 & $\underbrace{37}_{7}$ & $\underbrace{38}_{5}$ & 498 \\
\hline \multicolumn{2}{|c|}{$\begin{array}{c}\text { Gm. per kilo } \\
\text { body weight }\end{array}$} & & \multicolumn{2}{|c|}{0.294} & $4 \cdot 59$ & 0.585 & 0.091 & 0.054 & \multicolumn{2}{|c|}{0.454} & $3 \cdot 00$ \\
\hline \multicolumn{12}{|c|}{$\begin{array}{c}\text { Normal Controls } \\
\text { (10) }\end{array}$} \\
\hline \multicolumn{2}{|c|}{$\begin{array}{l}\text { Averages } \\
\text { mgm. }\end{array}$} & 168 & 23 & & 735 & 223 & 16 & 11 & \multicolumn{2}{|c|}{$\underbrace{34 \quad 32}$} & 417 \\
\hline \multicolumn{2}{|c|}{$\begin{array}{c}\text { Gm. per kilo } \\
\text { body weight }\end{array}$} & & \multicolumn{2}{|c|}{0.271} & $4 \cdot 38$ & $1 \cdot 33$ & 0.095 & 0.068 & \multicolumn{2}{|c|}{$0 \cdot 386$} & $2 \cdot 47$ \\
\hline
\end{tabular}

Table 4 gives the individual weights obtained at autopsy of the endocrine glands and of the uteri of the six active animals. It also gives the average weights for normal animals of approximately the same age. The only glands to show a definite change were the ovaries and the hypophysis. The weights of the ovaries of the experimental animals average $75 \mathrm{mgm}$., or $0.454 \mathrm{gm}$. per kilo body weight, while the weights of the ovaries of the controls averaged only $66 \mathrm{mgm}$., or $0.386 \mathrm{gm}$. per kilo body weight. In contrast, the weights of the pituitaries of the experimental animals averaged $9 \mathrm{mgm}$. or $0.054 \mathrm{gm}$. per kilo body weight, as compared with $11 \mathrm{mgm}$., or $0.068 \mathrm{gm}$. per kilo body weight. That the ovaries increased in weight while the hypophyses decreased is in agreement with our knowledge of the inverse relationship between these glands.

Unfortunately, we did not test the sex activity of these animals. The increased weight of the ovaries may indicate an increased secretory activity and, indirectly, increased sex activity. 
Changes in Behaviour.-All the rats with bilateral operations and most of the rats with unilateral operations became savage, bit at everything within reach, and made violent efforts to escape. They showed a high degree of distraction, reacting to the slightest noise, sometimes with a leap of several feet. Some of the rats showed a marked perseveration, noticeable especially when they ate or drank. Their chewing movements continued for some time after they had swallowed their food. In the same way, when drinking water from the inverted bottles they continued to lap the lip of the bottle long after their tongues no longer came into contact with the water. A tap on the cage quickly interrupted these perseveration tendencies.

Histological Studies.-All the brains were examined macroscopically. Eight of the brains were sectioned, stained, and studied microscopically. It was found that in all instances the lesion included the frontal cortex and at least a small amount of the anterior part of the striatum. Efforts to correlate differences in the increase in activity with the extent of the lesions were unsuccessful.

\section{Discussion}

These experiments show that rats may be made hyperactive by removal of the frontal poles of the brain (the cortex and the tip of the striatum). None of the animals actually ran itself to death, but in some of the rats the sharp decreases in activity and the disruption of the ovarian function lasting 10 to 15 days may indicate that a state of complete exhaustion had nearly been reached.

The condition of hyperactivity, increased distractability, increased irritability, and savageness when thwarted, as well as the possibly increased sex drive, presents a picture which closely resembles the manic condition seen in humans.

The mechanism involved in the production of these symptoms still remains unknown. The removal of the frontal poles may remove inhibitory influences, thus permitting every external stimulus to have an active effect ; or it may release energies which ordinarily are held in check or are released through other channels; and lastly, it may increase activity indirectly by permitting an increased secretory activity of the gonads.

We know from these experiments that a very high degree of hyperactivity may be produced by lesions limited to the frontal poles. It is possible, of course, that more extensive striatal or cortical lesions or lesions in other parts of the brain might produce as great or even greater increases in activity.

\section{Summary}

1. By means of activity drums and cyclometers, a quantitative study was made of the effects produced on spontaneous activity of rats by removal of the frontal poles of the brain (the cortex and the tip of the striatum).

2. Both unilateral as well as bilateral lesions increased activity greatly. Removal of both poles produced a condition of definite hyperactivity, that is, the rats reached activity levels never attained by normals. 
3. These lesions increased food intake, decreased body weight, but had no effect on water intake.

4. At autopsy the ovaries weighed more and the pituitaries less than those of control animals of the same age.

5. Since the animals became very distractible, irritable, and savage when thwarted, it was concluded that the picture presented greatly resembled that of manic conditions seen in humans.

\section{REFERENCES}

Richter, C. P. (1927). Quart. Rev. Biol., 2, 307.

Richter, C. P., and Hines, M. (1938). Brain, 61, 1.

Wang, G. H. (1923). Comp. Psychol. Monogr., 2, 1. 